\title{
SIE

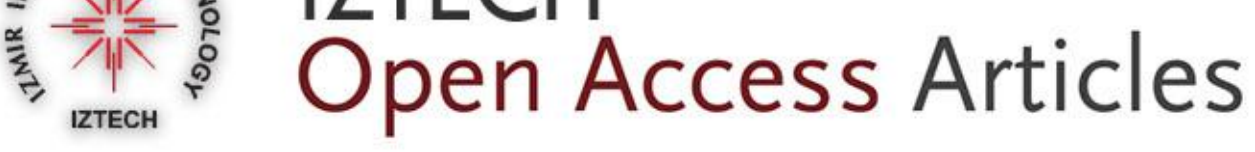

Hydrothermal synthesis and characterization of a novel supramolecular hybrid based on Keggin and $\mathrm{Cu}(\mathrm{I})$ complex

The IZTECH Faculty has made this article openly available. Please share how this access benefits you. Your story matters.

\begin{tabular}{|l|l|}
\hline Citation & $\begin{array}{l}\text { Emirdag-Eanes, M, Önen, Banu “Hydrothermal synthesis and } \\
\text { characterization of a novel supramolecular hybrid based on Keggin } \\
\text { and Cu(I) complex" INOCHE C 2013 Elsevier }\end{array}$ \\
\hline As Published & $10.1016 /$ j.inoche.2013.10.014 \\
\hline Publisher & ELSEVIER \\
\hline Version & UNCORRECTED PROOF \\
\hline Accessed & Tuesday September 24 10:27 GMT 2013 \\
\hline Citable Link & http://hdl.handle.net/11147/01 \\
\hline Terms of Use & $\begin{array}{l}\text { Article is made available in accordance with the publisher's policy } \\
\text { and may be subject to Turkish copyright law. Please refer to the } \\
\text { publisher's site for terms of use. }\end{array}$ \\
\hline Detailed Terms & \\
\hline
\end{tabular}




\section{AUTHOR QUERY FORM}

\begin{tabular}{|c|c|c|}
\hline 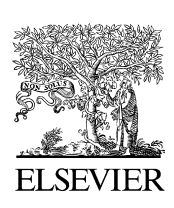 & $\begin{array}{l}\text { Journal: INOCHE } \\
\text { Article Number: } \mathbf{5 3 0 5}\end{array}$ & $\begin{array}{l}\text { Please e-mail or fax your responses and any corrections to: } \\
\text { Mahalakshmi Gunasekaran } \\
\text { E-mail: Corrections.ESCH@elsevier.spitech.com } \\
\text { Fax: +16196996721 }\end{array}$ \\
\hline
\end{tabular}

Dear Author,

Please check your proof carefully and mark all corrections at the appropriate place in the proof (e.g., by using on-screen annotation in the PDF file) or compile them in a separate list. Note: if you opt to annotate the file with software other than Adobe Reader then please also highlight the appropriate place in the PDF file. To ensure fast publication of your paper please return your corrections within 48 hours.

For correction or revision of any artwork, please consult http://www.elsevier.com/artworkinstructions.

Any queries or remarks that have arisen during the processing of your manuscript are listed below and highlighted by flags in the proof. Click on the 'Q' link to go to the location in the proof.

\begin{tabular}{|l|l|}
\hline Location in article & \multicolumn{1}{c|}{$\begin{array}{c}\text { Query / Remark: click on the Q link to go } \\
\text { Please insert your reply or correction at the corresponding line in the proof }\end{array}$} \\
\hline Q1 & Please confirm that given names and surnames have been identified correctly. \\
\hline Q2, Q3, Q4, Q5 & Please provide a caption. \\
\hline$\underline{\text { Q6, Q7, Q8 }}$ & $\begin{array}{l}\text { Supplementary caption was not provided. Please check suggested data if appropriate and correct if } \\
\text { necessary. }\end{array}$ \\
\hline$\underline{\text { Q9 }}$ & $\begin{array}{l}\text { Figure } 4 \text { is captured after the Reference section as reducing them would affect the quality and } \\
\text { readability of the figure. Please advise if action done is appropriate. }\end{array}$ \\
& $\begin{array}{l}\text { Please check this box if you have no } \\
\text { corrections to make to the PDF file. }\end{array}$ \\
\hline
\end{tabular}

Thank you for your assistance. 


\section{Graphical abstract}

Mehtap Emirdag-Eanes *, Banu Önen

Inorganic Chemistry Communications $x x x(2013) x x x-x x x$

Hydrothermal synthesis and characterization of a novel supramolecular hybrid based on Keggin and $\mathrm{Cu}(\mathrm{I})$ complex
Structure of $\left[\mathrm{Cu}\left(4,4^{\prime} \text { bipyH }\right)_{3}(4,4\right.$ bipy $\left.)\right]\left[\mathrm{HPW}_{12} \mathrm{O}_{40}\right]_{2} .12-$ $\mathrm{H}_{2} \mathrm{O}$ consists of two Kegging polyoxoanion connected with $\mathrm{Cu}$ complex fragment forming a big molecule that extends in 3D via hydrogen bonding. 
Hydrothermal synthesis and characterization of a novel supramolecular hybrid based on Keggin and $\mathrm{Cu}(\mathrm{I})$ complex

Mehtap Emirdag-Eanes *, Banu Önen

Izmir Institute of Technology, Faculty of Science, Deparment of Chemistry Gulbahce, 35430 Izmir Turkey

- $\left[\mathrm{Cu}\left(4,4^{\prime} \text { bipyH }\right)_{3}(4,4\right.$ bipy $\left.)\right]\left[\mathrm{HPW}_{12} \mathrm{O}_{40}\right]_{2} \cdot 12 \mathrm{H}_{2} \mathrm{O}$ were sythesized using hydrothermal method.

- The effect of pH of reaction media is studied.

- Purple crystals were analysed using IR, UV and X-ray diffraction.

- Molecule extends in 3D through hydrogen bonding. 
Q6 Supplementary material 1.

Q7 Supplementary material 2 .

Q8 Supplementary material 3.

Table S2 Selected bond distances $\left(\mathrm{A}^{\circ}\right)$ for $\left[\mathrm{Cu}\left(4,4^{\prime} \mathrm{bipyH}\right)_{3}(4,4 \mathrm{bipy})\right]\left[\mathrm{HPW}_{12} \mathrm{O}_{40}\right]_{2} \cdot 12 \mathrm{H}_{2} \mathrm{O}$. 


\title{
Hydrothermal synthesis and characterization of a novel supramolecular hybrid based on Keggin and $\mathrm{Cu}(\mathrm{I})$ complex
}

\author{
Q1 Mehtap Emirdag-Eanes *, Banu Önen
}

Izmir Institute of Technology, Faculty of Science, Deparment of Chemistry Gulbahce, 35430 Izmir Turkey

\section{A R T I C L E I N F O}

\section{Article history:}

Received 24 July 2013

Accepted 9 October 2013

Available online xxxx

\section{Keywords:}

Hydrothermal

Keggin

Polyoxoanion

Hybrid

\begin{abstract}
A B S T R A C T
A novel inorganic-organic hybrid molecule, $\left[\mathrm{Cu}\left(4,4^{\prime} \text { bipyH }\right)_{3}(4,4\right.$ bipy $\left.)\right]\left[\mathrm{HPW}_{12} \mathrm{O}_{40}\right]_{2} \cdot 12 \mathrm{H}_{2} \mathrm{O}(\mathbf{1})$, has been 19 hydrothermally synthesized and characterized by IR spectra, TG and single crystal X-ray diffraction analyses. 20 Structural analysis reveals that the novel compound $\mathbf{1}$ composed of two Kegging polyoxoanion connected with 21 $\mathrm{Cu}$ complex fragment forming a big molecule that extends in 3D via hydrogen bonding.
\end{abstract}

(C) 2013 Published by Elsevier B.V. 23
Polyoxometallates (POMs) [1] have attracted great interest due to their structural diversity, electronic versatility, which enables them to have great potential applications in catalysis, magnetism, electrochemistry and photochemistry [2-6], and outstanding ability of constructing inorganic-organic hybrid materials. Recently the number of strategies designing inorganic-organic hybrid materials based on POMs has been developed [7]. One of the approaches to connect POM units with organic ligands is to use secondary transition metal acting as inorganic bridging groups under hydrothermal conditions. Inorganicorganic hybrid materials receive great attention because of the potential applications such as catalysis, ion exchange and medicine [8-10]. Design and synthesis of the novel inorganic-organic solid materials based on POMs and transition metal complexes of various organic groups provide combining the future and properties of both subunits (organic ligands or transition metal complexes) and POMs to increase the functionality of the hybrid materials. Some successful examples of Keggin polyoxometalates with copper complexes include $\left(\mathrm{C}_{20} \mathrm{H}_{16} \mathrm{CuN}_{4}\right)_{5}\left(\mathrm{PW}_{12}\right.$ $\left.\mathrm{O}_{40}\right) \cdot 2\left(\mathrm{H}_{2} \mathrm{O}\right)$ [11], $\left(\mathrm{C}_{20} \mathrm{H}_{16} \mathrm{CuN}_{4}\right)_{3}\left(\mathrm{PW}_{12} \mathrm{O}_{40}\right)$ [12], $\left(\mathrm{C}_{24} \mathrm{H}_{16} \mathrm{CuN}_{4}\right)_{3}\left(\mathrm{PW}_{12-}\right.$ $\left.\mathrm{O}_{40}\right)$ [13], $\left(\mathrm{PW}_{12} \mathrm{O}_{40}\right) \mathrm{nn}\left(\mathrm{C}_{20} \mathrm{H}_{16} \mathrm{CuN}_{4}\right)_{3} \quad 4 \mathrm{n}\left(\mathrm{C}_{20} \mathrm{H}_{14} \mathrm{Cu}_{2} \mathrm{~N}_{4} \mathrm{O}_{2}\right)_{3} .2 \mathrm{n}\left(\mathrm{H}_{2} \mathrm{O}\right)$ [14], $\left(\mathrm{C}_{24} \mathrm{H}_{17} \mathrm{CuN}_{4}\right)\left(\mathrm{PW}_{12} \mathrm{O}_{40}\right)\left(\mathrm{C}_{12} \mathrm{H}_{8} \mathrm{~N}_{2}\right)$ [15]. Additionally, a number of the Keggin structures with $\mathrm{Si}$ atom in the middle have been reported [16-20]. However Kegging with $\mathrm{P}$ atom in the middle with copper complexes are fewer. As a part of the continuing efforts in the construction of inorganic-organic hybrid materials herein we report a novel copper tungstate with 4,4'-bipyridine ligand, $\left[\mathrm{Cu}\left(4,4^{\prime} \text { bipyH }\right)_{3}(4,4\right.$ bipy $\left.)\right]\left[\mathrm{HPW}_{12} \mathrm{O}_{40}\right]_{2} \cdot 12 \mathrm{H}_{2} \mathrm{O}$.

\footnotetext{
* Corresponding author at: Izmir Yuksek Teknoloji Enstitusu, Fen Fakultesi Kimya Bolumu, Gulbahce koyu, 35430 Izmir, Turkey. Tel.: + 902327507564 ; fax: + 902327507509. E-mail address: mehtapemirdag@iyte.edu.tr (M. Emirdag-Eanes).
}

All chemicals were obtained commercially and used without further 54 purification. Crystals of $\left[\mathrm{Cu}\left(4,4^{\prime} \text { bipyH }\right)_{3}(4,4\right.$ bipy $\left.)\right]\left[\mathrm{HPW}_{12} \mathrm{O}_{40}\right]_{2} .12 \mathrm{H}_{2} \mathrm{O} 55$ were synthesized with a mixture of $\mathrm{Na}_{6}\left[\mathrm{H}_{2} \mathrm{~W}_{12} \mathrm{O}_{40}\right](0.1 \mathrm{mmol}$, Alfa 56 Easer 99\%), $\mathrm{CuCl}_{2} \cdot 2 \mathrm{H}_{2} \mathrm{O}$ (0.5 mmol, Merck $\geq 99 \%$ ), 4,4'-bipyridine 57 ( $0.5 \mathrm{mmol}$, Alfa Aesar $98 \%$ ) and $\mathrm{H}_{3} \mathrm{PO}_{4}(0.3 \mathrm{mmol}$, Sigma-Aldrich, $85 \%) .58$ The mixture was stirred for $1 \mathrm{~h}$ then transferred to a Teflon-lined 59 autoclave $(23 \mathrm{~mL})$ and heated at $170{ }^{\circ} \mathrm{C}$ for 3 days. After cooling to 60 room temperature, the mixture of greenish powder, clear and purple 61 crystals was filtered off, washed with distilled water and acetone. 62 Hydrothermal reaction for the title compound yielded a purple plate 63 of $\left[\mathrm{Cu}\left(4,4^{\prime} \text {-Hbipy }\right)_{4}\right]\left[\mathrm{HPW}_{12} \mathrm{O}_{40}\right]_{2} \cdot 12 \mathrm{H}_{2} \mathrm{O}$ as a minor product. Other 64 products were a mix of greenish unidentified powder and clear crystals 65 of novel $\left.\left[4,4^{\prime} \mathrm{bpyH}_{2}\right)_{2}\left(4,4^{\prime} \mathrm{bpyH}\right)\right]\left[\mathrm{PCuW}_{11} \mathrm{O}_{39}\right] \cdot \mathrm{H}_{2} \mathrm{O}$ 1D Kegging chain 66 that will be discussed with other similar structures in another paper. 67 Synthesis of the title compound was done at $\mathrm{pH} 2.8$. It is known that $\mathrm{pH} 68$ plays an important role to synthesize different type of POM compounds 69 [21]. Synthesis was tried in different $\mathrm{pH}$ values and it is observed that 70 even small changes of $\mathrm{pH}$ affect the type of the crystals obtained. The 71 $\mathrm{pH}$ studies were at $20^{\circ} \mathrm{C}$, pH values between 2.2 and 2.7 only resulted 72 in clear crystals however after pH 2.8 the purple crystals started to be 73 formed. The formation of different crystals is shown in Scheme 1.

A purple plate single crystal with dimensions $0.15 \times 0.14 \times 0.05 \mathrm{~mm}^{3} \quad 75$ of the compound (I) was carefully selected and mounted on a glass fiber. 76 The data was collected on Bruker APEK-II CCD diffractometer at $100 \mathrm{~K} 77$ using a graphite-monochromate Mo $\mathrm{K} \alpha$ radiation $(\lambda=0.71073 \AA$ ). 78 The structure of (I) was solved by direct method using SHELXL97 79 software $[22,23]$ and refined by using least square methods. All of the 80 heavy atoms were refined anisotropically. The positions of the hydrogen 81 atoms attached to carbon atoms were fixed at their ideal positions with 82 Ueq set at 1.2Ueq. Hydrogens attached to oxygen atoms of water were 83 not located. Crystallographic data for the structure reported has been 84 


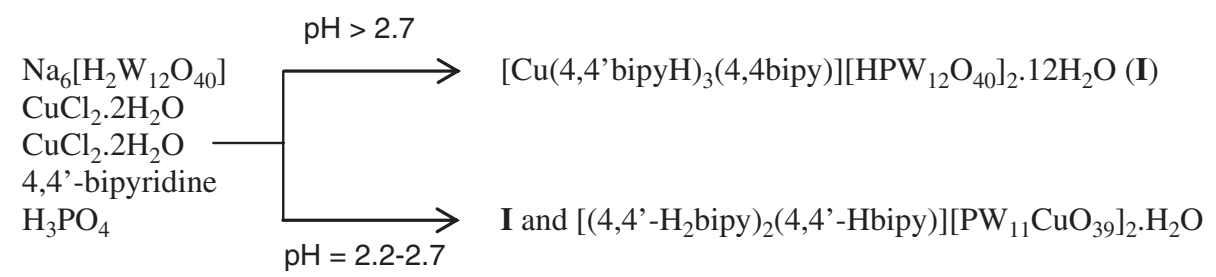

Scheme 1. Schematic illustration of the synthesis route of title compound.

deposited with Cambridge Crystallographic Data Center, CCDC No 934771. During the structure solution, the program suggested the space group Pbcn, and the structure was solved based on this space group. However the R value was slightly high. When the systematic absences were checked, there was an ambiguity on the reflection $h 0 l$. Based on the systematic absences on $h 0 l, l$ could be absent or not. The structure was analyzed for both cases. When $l$ was absent, the suggested space group was $\mathrm{Pnca}(\mathrm{Pbcn})$ of which we initially tried to solve. When $l$ was not absent there were two choices of the space group, Pnma and $\mathrm{Pn} 2_{1} a$. First Pnma was chosen and applied to structure but the result was not very successful. Prior to applying noncentrosymmetric $\mathrm{Pn} 2_{1} a$, space group was transformed to standard setting of $\mathrm{Pna}_{1}$ using transformation matrix. Finally Pna2 ${ }_{1}$ was applied as the space group. As a result the structure solution was done successfully with a low $R$ value. Crystallographic information is given in Table 1.

The IR spectra were obtained on a Perkin-Elmer Spectrum 100 FT-IR spectrometer with $\mathrm{KBr}$ pellets in the $400-4000 \mathrm{~cm}^{-1}$ region. Keggin type of POMs can be identified with two regions in the IR spectrum (Fig. 1a). The first region over $1200 \mathrm{~cm}^{-1}$ is indicative of 4,4'bipyridine ligand. Second region below $1200 \mathrm{~cm}^{-1}$ would have the characteristic bands for Keggin structure. The P-O vibrations are observed at $1081 \mathrm{~cm}^{-1}$. The bands of $950-980 \mathrm{~cm}^{-1}$ are assigned to $\mathrm{W}=\mathrm{O}_{t}$ stretching vibrations. Bands between 750 and $800 \mathrm{~cm}^{-1}$ are attributed to $\mathrm{W}-\mathrm{O}_{b}-\mathrm{W}$ stretching and bands between 500 and $700 \mathrm{~cm}^{-1}$ corresponds to $\mathrm{W}-\mathrm{O}_{c}-\mathrm{W}$ vibrations.

To gain knowledge relating to the thermal stability of the synthesized organo-POM compound, the termal gravimetric analyses (TGA) were

Table 1

Crystallographic data for $\left[\mathrm{Cu}\left(4,4^{\prime} \text { bipyH }\right)_{3}(4,4\right.$ bipy $\left.)\right]\left[\mathrm{HPW}_{12} \mathrm{O}_{40}\right]_{2} \cdot 12 \mathrm{H}_{2} \mathrm{O}$.

\begin{tabular}{|c|c|}
\hline Formula & $\mathrm{PW}_{24} \mathrm{O}_{92} \mathrm{CuC}_{40} \mathrm{~N}_{8} \mathrm{H}_{32}$ \\
\hline Formula weight & 6634.62 \\
\hline Space group & Pna2(1) \\
\hline $\mathrm{a}, \AA$ & $20.185(5)$ \\
\hline b, $\AA$ & $25.633(5)$ \\
\hline c, $\AA$ & $20.199(5)$ \\
\hline$\alpha,{ }^{\circ}$ & 90 \\
\hline$\beta,^{\circ}$ & 90 \\
\hline$\gamma$, & 90 \\
\hline $\mathrm{V}, \AA^{3}$ & $10,451(4)$ \\
\hline $\mathrm{Z}$ & 4 \\
\hline $\mathrm{D}_{\text {calc }}, \mathrm{Mg} / \mathrm{m}^{3}$ & 4.217 \\
\hline Parameters & 805 \\
\hline$\mu, \mathrm{mm}^{-1}$ & 26.64 \\
\hline$\theta$ range, $^{\circ}$ & $2.39-29.2$ \\
\hline \multicolumn{2}{|l|}{ Reflections } \\
\hline Collected & 93,382 \\
\hline Independent & 26,437 \\
\hline Observed $[\mathrm{I} \geq 2 \sigma(\mathrm{I})]$ & 22,796 \\
\hline $\mathrm{R}$ (int) & 0.045 \\
\hline \multicolumn{2}{|l|}{ Final R (obs. data) ${ }^{\mathrm{a}}$} \\
\hline $\mathrm{R}_{1}$ & 0.0323 \\
\hline $\mathrm{wR}_{2}$ & 0.0722 \\
\hline \multicolumn{2}{|l|}{ Final R (all data) } \\
\hline $\mathrm{R}_{1}$ & 0.0437 \\
\hline $\mathrm{wR}_{2}$ & 0.0764 \\
\hline Goodness of fit on $\mathrm{F}^{2}$ & 1.026 \\
\hline Largest diff. peak, e $/ \AA^{3}$ & 3.074 \\
\hline Largest diff. hole, e $/ \AA^{3}$ & -2.846 \\
\hline
\end{tabular}

${ }^{a} R_{1}=\left[\sum|| F_{0}|-| F_{c} \|\right] / \sum\left|F_{0}\right| ; w R_{2}=\left\{\left[\sum w\left[\left(F_{0}\right)^{2}-\left(F_{c}\right)^{2}\right]^{2}\right]\right\}^{1 / 2}$. carried out on the 2962 SDT simultaneous DSC-TGA instruments in 112 flowing $\mathrm{N}_{2}$ with a heating rate of $20^{\circ} \mathrm{C} /$ min.TG curves (Fig. 1b) of the 113 title compound undergo two step weight loss. First weight loss of 114 $3245 \%$ (calcd. 3.2\%) between 100 and $340^{\circ} \mathrm{C}$ was assigned to the 115 removal of the lattice water molecules. The second continuous weight 116 loss of approximately \%13 (calcd. 13\%), in the temperature range 340- 117 $550^{\circ} \mathrm{C}$, corresponds to the release of four bipy molecules coordinated 118 with $\mathrm{Cu}^{1}$. The weight loss progress is well consistent with similar 119 compounds in the literature [24].

The single crystal X-ray structural analysis shows that the crystals 121 of the title compound contain two Keggin $\left[\mathrm{HPW}_{12} \mathrm{O}_{40}\right]^{2-}$ clusters, 122 $\left[\mathrm{Cu}\left(4,4^{\prime} \text { 'bipyH }\right)_{3}(4,4 \text { bipy })\right]^{4+}$ complex and water molecules. Keggin 123 polyoxotungstate structure composed of 12 tungsten atoms surrounded 124 by three different types of oxygens, terrminal, bridging and central. All 125

a)

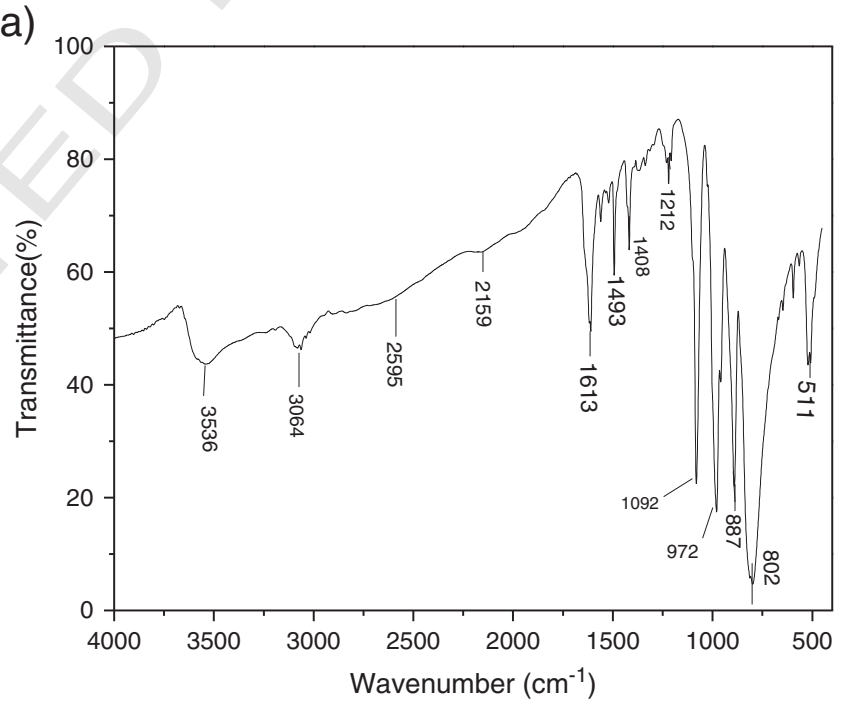

b)

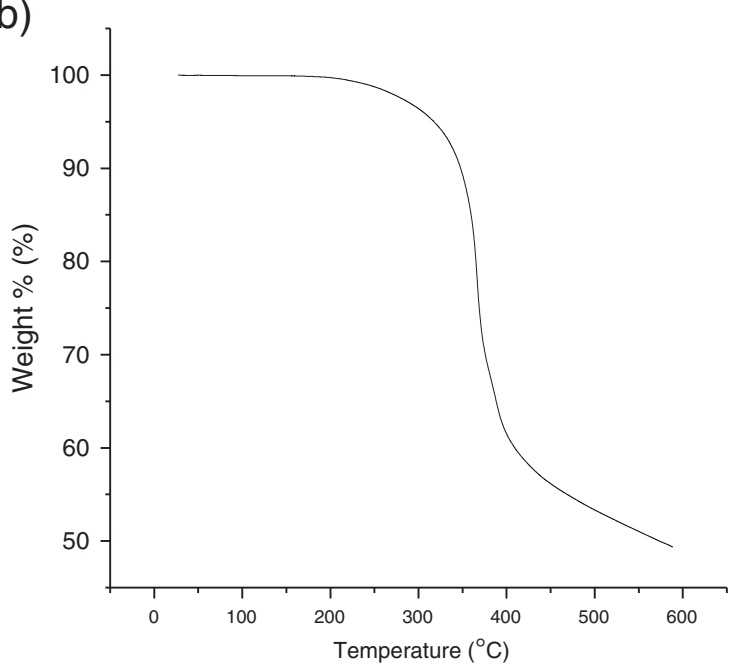

Fig. 1. 


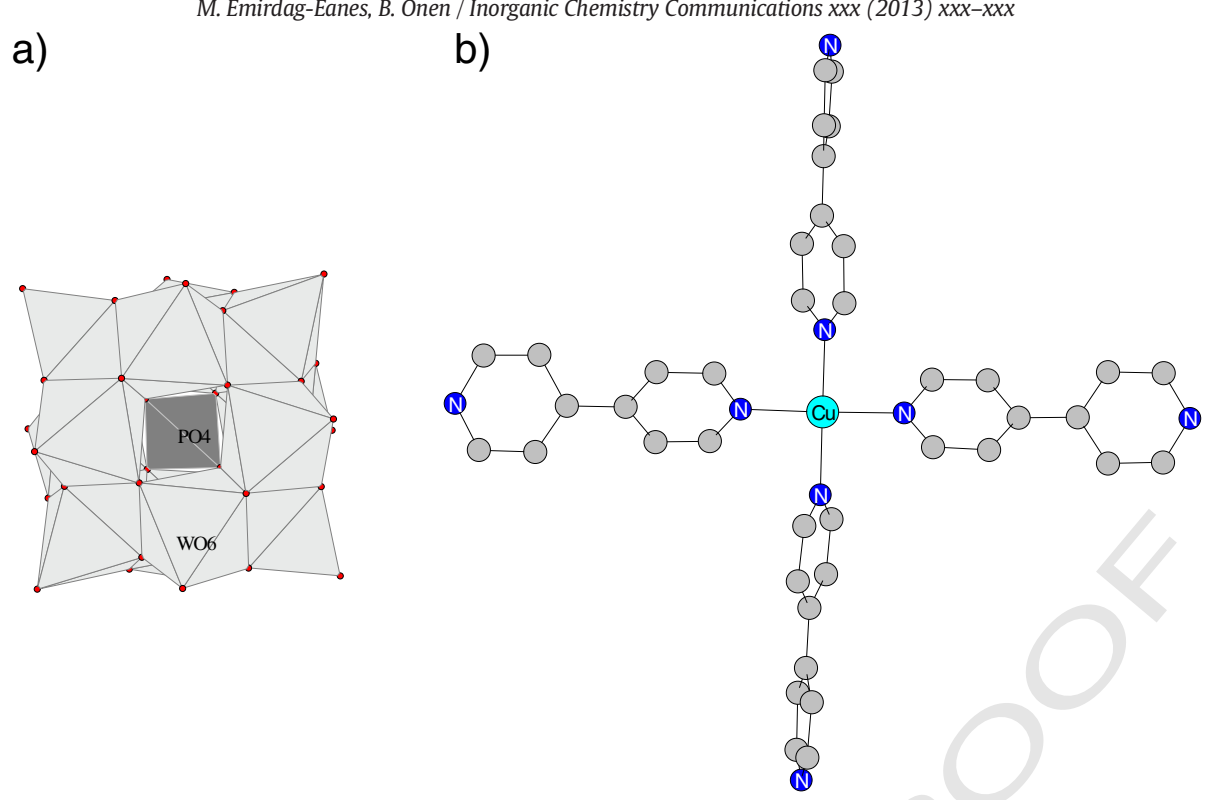

Fig. 2.

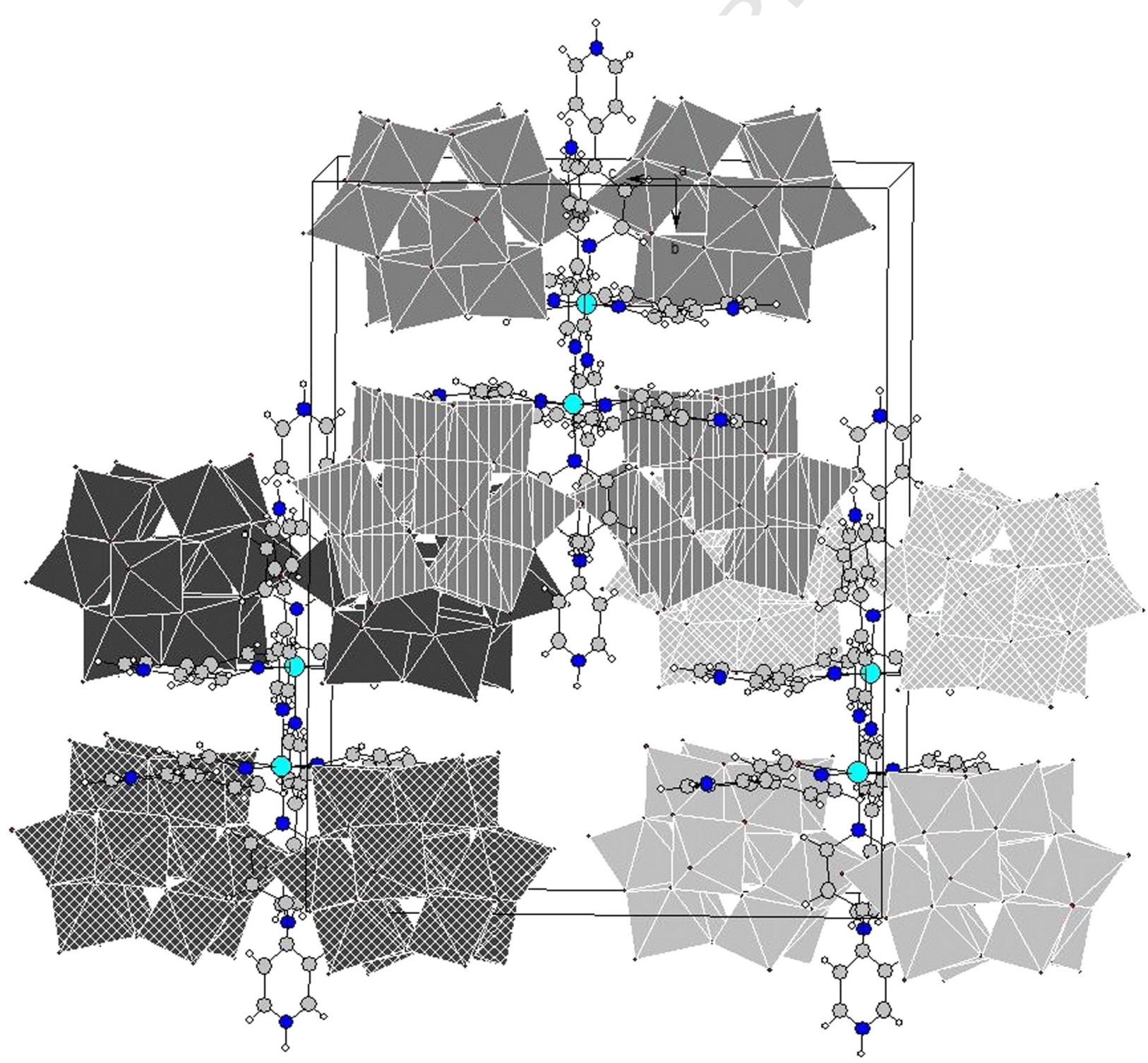

Fig. 3.

Please cite this article as: M. Emirdag-Eanes, B. Önen, Hydrothermal synthesis and characterization of a novel supramolecular hybrid based on Keggin and $\mathrm{Cu}(\mathrm{I})$ complex, Inorg. Chem. Commun. (2013), http://dx.doi.org/10.1016/j.inoche.2013.10.014 
the tungsten atoms have one short bond to terminal oxygen with the average distance of $1.700(14) \AA$, four bonds to bridging oxygens ranging from 1.867(9) to 1.951(10) $\AA$ and one long bond to central oxygens with the average distance of 2.43(19) Å forming an octahedra. Keggin structure consists of $\mathrm{WO}_{6}$ octahedra units linked by both corner and edge sharing interactions. Three $\mathrm{WO}_{6}$ octahedras sharing edges form a $\mathrm{W}_{3} \mathrm{O}_{13}$ units four of which encapsulating $\mathrm{PO}_{4}$ tetrahedra shares corners to form Kegging structure (Fig. 2a). The central P atom in the compound is tetrahedrally coordinated to central oxygen atoms with the average bond distance of
1.528(9) Å. Connections between two Keggin cages are made through 135 transition metal complex fragment, $\left[\mathrm{Cu}\left(4,4^{\prime} \text { bipyH }\right)_{3}(4,4 \text { bipy })\right]^{4+}$, to form 136 a large molecule of two kegging cage and $\mathrm{Cu}$ complex. The $\mathrm{Cu}^{1+}$ ion 137 forms a complex with four 4,4'bipyridine ligands connected through 138 nitrogen atoms (Fig. 2). Three of the organic ligands, 4,4'bipyridine, in 139 the complex fragment are monoprotonated, meaning they adopt the 140 mono-dentate mode which terminates the extensibility of the structure. 141 The $\mathrm{Cu}-\mathrm{N}$ bond distances ranges from 2.002(8) to 2.033(9) A. Each 142 $\left[\mathrm{Cu}\left(4,4^{\prime} \text { bipyH }\right)_{3}(4,4 \text { bipy })\right]^{4+}$ fragments is located between two 143

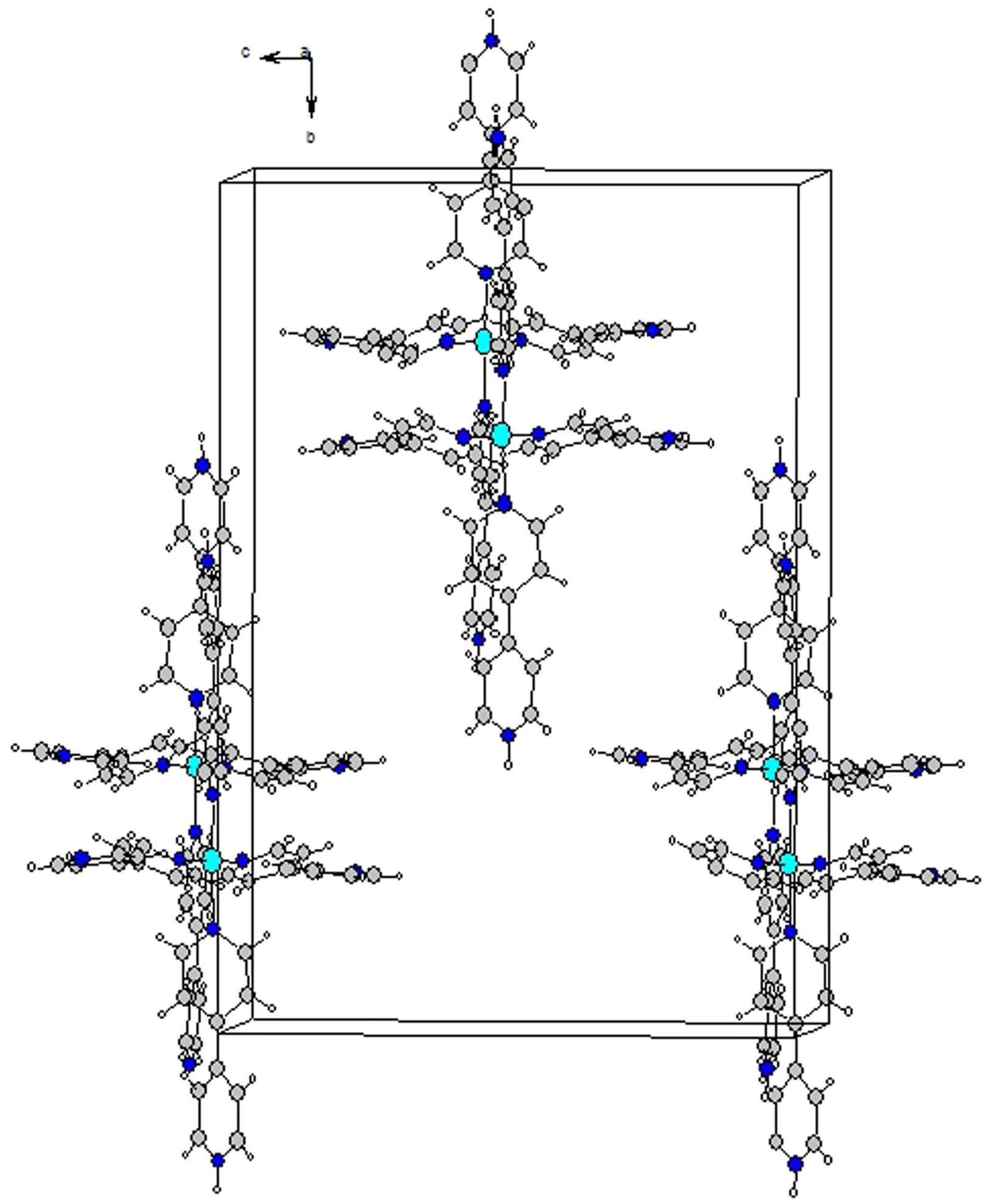

Fig. 4. 
polyoxotungstate clusters and the connection is made through $\mathrm{Cu}-$ Ot bonds with the interactions ranging from 2.409(9) to 2.477(8) $\AA$ A. Four of these large molecules form the unit cell of the title compound (Fig. 3). There is no connection between molecules except $\mathrm{H}$ bonding. Extention of the structure in 3D is constituted via hydrogen bonds. In Fig. 3, all the discrete molecules can be seen in different colors and styles. These molecules are located in the cell according to space group of Pna $2_{1}$. Fig. 4 is given to show the Cu complexes in the cell to have a better understanding of arrangement of the molecules and the structure. Selected bond distances are given in Table S1.

The valence bond sum calculations [25] confirm that all $\mathrm{W}$ and $\mathrm{Cu}$ bonds are +6 and +1 respectively. Reduction of the copper atom $\left(\mathrm{Cu}^{\mathrm{II}} \rightarrow \mathrm{Cu}^{\mathrm{I}}\right)$ may be due to the addition of $4,4^{\prime}$ bipyridine ligands [26,27]. For the charge balance and the coordination environments three of the uncoordinated nitrogen atoms (N10, N35 and N36) in the organic ligand are protonated, which is similar to the reported cases.[21,28].

There is an extensive hydrogen bonding among the lattice water molecules and oxygen atoms from the POMs, some of the representative hydrogen bonds are 0750.....031 $2.828 \AA$, 0751...035 $2.921 \AA$, and O750...017 2.841 A. The water molecules of the title compound also have interactions with the hydrogen atoms on the 4,4'bipyridine fragments via $\mathrm{C}-\mathrm{H} . . . \mathrm{O}$ or $\mathrm{N}-\mathrm{H}$...O hydrogen bonding. These hydrogen bonding interactions make the Keggin polyoxoanions and the complex cation, $\left[\mathrm{Cu}\left(4,4^{\prime} \text { bipyH }\right)_{3}(4,4 \text { bipy })\right]^{4+}$, forming a 3D supramolecular network. The $\mathrm{O}-\mathrm{H}$...O hydrogen bonds also exist between two Kegging molecule in the title compound, as well. The 049 from one POM is connected to $\mathrm{O} 22$ from the other POM through hydrogen bonds with distance of $2.784 \AA$. The same type of interaction is also seen between 056 and 019 with distance of $2.773 \AA$. Based on these observations in the structure, position of the $\mathrm{H}$ atom in the $\left[\mathrm{HPW}_{12} \mathrm{O}_{40}\right]^{4-}$ fragment can be assigned to 056 in one of the Kegging and 049 in the other Keggin cage.

In summary, a novel inorganic-organic hybrid material based on Keggin POMs, $\left[\mathrm{Cu}\left(4,4^{\prime} \text { bipyH }\right)_{3}(4,4\right.$ bipy $\left.)\right]\left[\mathrm{HPW}_{12} \mathrm{O}_{40}\right]_{2} .12 \mathrm{H}_{2} \mathrm{O}$, has been synthesized and structurally characterized. The $\mathrm{pH}$ value of the reaction system plays an important role in the structure type and the yield of obtained product. While $\left[\left(4,4^{\prime}-\mathrm{H}_{2} \text { bipy }\right)_{2}\left(4,4^{\prime}-\mathrm{Hbipy}\right)\right]$ $\left[\mathrm{PW}_{11} \mathrm{CuO}_{39}\right]_{2} \cdot \mathrm{H}_{2} \mathrm{O}$ is the only product in lower $\mathrm{pH}$, title compound was obtained at higher $\mathrm{pH}$ values.

\section{Acknowledgments}

This work was financially supported by TUBITAK (109 T903). We thank Professor T. Linden from the Department of Chemistry of University of Zurich in Switzerland for helpful discussion on structure solution. We also thank J. Renee Eanes for English proofreading of the manuscript.

\section{Appendix A. Supplementary material}

CCDC 934771 contains the supplementary crystallographic data for this paper. This data can be obtained free of charge from The Cambridge Crystallographic Data Centre via www.ccdc.cam.ac.uk/data_request/cif. Supplementary data associated with this article can be found, in the online version. Supplementary data to this article can be found online at http://dx.doi.org/10.1016/j.inoche.2013.10.014.

\section{Appendix A. Supplementary material}

Supplementary data to this article can be found online at http://dx. doi.org/10.1016/j.inoche.2013.10.014.

\section{References}

1] M.T. Pope, Heteropoly and Isopoly Oxometalates, Springer-Verlag, Berlin, 1983.

[2] A. Muller, et al., Polyoxometalates: very large clusters - nanoscale magnets, Chem. 200 Rev. 98 (1) (1998) 239-271.

[3] C.Y. Sun, et al., Highly stable crystalline catalysts based on a microporous 202 metal-organic framework and polyoxometalates, J. Am. Chem. Soc. 131 (5) (2009) 203 1883-1888.

[4] S. Cardona-Serra, et al., Lanthanoid single-1on magnets based on polyoxometalates 205 with a 5-fold symmetry: the series $\operatorname{LnP}(5) \mathrm{W}(30) \mathrm{O}(110)(12-)(\operatorname{Ln}(3+)=\mathrm{Tb}, \mathrm{Dy}, 206$ Ho, Er, Tm, and Yb), J. Am. Chem. Soc. 134 (36) (2012) 14982-14990.

[5] D. Hagrman, P.J. Hagrman, J. Zubieta, Solid-state coordination chemistry: the 208 self-assembly of microporous organic-inorganic hybrid frameworks constructed 209 from tetrapyridylporphyrin and bimetallic oxide chains or oxide clusters, Angew. 210 Chem. Int. Ed. 38 (21) (1999) 3165-3168.

[6] T. Yamase, Photochemıcal studies of the alkylammonıum molybdates.7. Octahedral 212 sites for multielectron reduction of M08026(M004)2 8, J. Chem. Soc. Dalton Trans. 213 (12) (1985) 2585-2590.

[7] Rongmin Yua, et al., Stabilization and immobilization of polyoxometalates in porous 215 coordination polymers through host-guest interactions, Coord. Chem. Rev. 253216 (23-24) (2009) 2872-2890.

[8] C.L. Hill, e., Polyoxometalates, Chem. Rev. 98 (1998) 1-387. M.T. Pope, A. Muller, Polyoxometalate chemistry - an old field with new dimensions 219 in several disciplınes, Angew. Chem. Int. Ed. Engl. 30 (1) (1991) 34-48. 220

[10] J.Q. Sha, et al., Hydrothermal syntheses and crystal structures of hybrid materials 221 based on Keggin cluster modified by iron complexes, J. Coord. Chem. 61 (8) 222 (2008) 1221-1233.

[11] L. Bai, et al., Hydrothermal synthesis, crystal structures and electrochemical 224 properties of two phosphatotungstates containing Keggin clusters, Cu(2,2 '-bipy)(2) 225 (5) PW12040 center dot 2H(2)O and (Hpip)(3) PW12040, J. Clust. Sci. 19 (4) 226 (2008) 561-572.

[12] T.Y. Lan, et al., Hydrothermal synthesis, crystal structure and fluorescent property of 228 a Keggin polyoxometalate Cu-I(2,2 '-bipy)213 (PW12040)-O-VI, Chin. J. Struct. 229 Chem. 25 (3) (2006) 368-373.

[13] H.N. Chen, et al., Polyoxotungstate clusters: syntheses, characterization, and crystal 231 structures of CuII(1,3-dap)2 2 CulI(1,3-dap) 2H-PW10.5 image omitted 040 and 232 CuI(phen)2 3-PW12040, J. Coord. Chem. 63 (9) (2010) 1463-1472. 233

[14] C.M. Wang, S.T. Zheng, G.Y. Yang, Novel hybrids constructed from 234 keggin-polyoxometalate and mixed copper complex, J. Clust. Sci. 20 (3) (2009) 235 489-501.

15] Y. Yuan, Q.S. Wang, S.M. Wang, New supramolecular compound based on poly- 237 oxomet Cu(phen)(2)(HPW12040). (Phen): synthesis and crystal structure, Chin. J. 238 Inorg. Chem. 26 (11) (2010) 2105-2108.

[16] C.H. Li, et al., Synthesis, crystal structure and electrochemical properties of 240 complex Cu-2(phen)(2) (SiW12O40)(H2O)(7), Chin. J. Inorg. Chem. 22 (6) (2006) 241 $1072-1076$.

[17] H. Jin, et al., Cu(5)C1(4,4 '-bipy)(5) SiW12040 center dot 1.5H(2)O: a 243 novel three-dimensional framework constructed from polyoxometalate 244 clusters and trinuclear Cu(I) complex, Inorg. Chem. Commun. 9 (5) (2006) 245 482-485.

[18] F.X. Meng, et al., Metal-oxo cluster-supported transition metal complexes: 247 hydrothermal synthesis and characterization of $\{\mathrm{Cu}(\mathrm{phen})(2)\}(2) \mathrm{SiW} 12040,248$ J. Coord. Chem. 60 (4) (2007) 401-410. Cu-I(phen)(2) (4)(SiW12040), Chin. J. Struct. 251 Chem. 27 (5) (2008) 605-609. 252

[20] X.L. Wang, et al., Two new inorganic-organic hybrid compounds templated by 253 SiW120404- anion with nonlinear ligands, Solid State Sci. 13 (2) (2011) 254 344-349.

[21] H.X. Yang, et al., Syntheses, structures, and properties of a series of supramolecular 256 hybrids based on Keggin or Wells-Dawson polyoxometalates and 4,4'-bipyridines, 257 J. Mol. Struct. 966 (1-3) (2010) 33-38. 258

[22] G.M. Sheldrick, Program for crystal structure refinement, University of Göttingen, 259 Germany, 1997.

[23] G.M. Sheldrick, Program for crystal structure solution, University of Göttingen, 261 Germany, 1997.

[24] X.M. Lu, et al., The assembly of phosphometalate clusters with copper complex 263 subunits, Eur. J. Inorg. Chem. 34 (2009) 5267-5276.

[25] I.D. Brown, Bond-valence parameters obtained from a systematic analysis of the 265 Inorganic Crystal Structure Database, Acta Crystallogr. B Struct. Sci. 41 (4) (1985) 266 244-247.

[26] X.J. Kong, et al., Construction of polyoxometalates-based coordination polymers 268 through direct incorporation between polyoxometalates and the voids in a 2D 269 network, Inorg. Chem. 45 (26) (2006) 10702-10711.

[27] P.Q. Zheng, et al., pH-dependent assembly of Keggin-based supramolecular 271 architecture, Inorg. Chem. 44 (5) (2005) 1190-1192.

[28] P.P. Zhang, et al., Two new organic-inorganic supramolecular hybrids 273 templated by the Wells-Dawson polyoxometalates, J. Mol. Struct. 968 (1-3) (2010) 274 19-23. 